\title{
Daily Migration and Contribution of Calanoida Zooplankton to Scattering Volume in Banda Sea, Indonesia
}

\author{
Domey Moniharapon \\ Department of Marine Sciences and Technology, Faculty of Fisheries and Marine \\ Science, Bogor Agricultural University, Bogor, Indonesia \\ Program of Marine Science, Faculty of Fisheries and Marine Sciences, University of \\ Pattimura, Jl Ir M Putuhena, Campus Poka, Ambon
}

Indra Jaya

Department of Marine Sciences and Technology, Faculty of Fisheries and Marine Science, Bogor Agricultural University, Bogor, Indonesia

\section{Henry Manik}

Department of Marine Sciences and Technology, Faculty of Fisheries and Marine Science, Bogor Agricultural University, Bogor, Indonesia

\section{Sri Pujiyati}

Department of Marine Sciences and Technology, Faculty of Fisheries and Marine Science, Bogor Agricultural University, Bogor, Indonesia

\section{Totok Hestirianoto}

Department of Marine Sciences and Technology, Faculty of Fisheries and Marine Science, Bogor Agricultural University, Bogor, Indonesia

Augy Syaihailatua

Marine Life Conservation 3.Balai Ambon. Indonesian Institute of Sciences. Jl.Guru-guru Batukoneng, Ambon 


\title{
Macrothink
}

Received: May 6, 2014 Accepted: June 9, 2014 Published: June 27, 2014

doi:10.5296/jee.v5i1.5879ＵRL: http://dx.doi.org/10.5296/jee.v5i1.5879

\begin{abstract}
The study aims to analyze daily migration of zooplankton in Banda Sea and contribution of Calanoida to scattering volume. Applied method is exploratory description through direct survey toward zooplankton by using Baruna Jaya VII vessel as floating platform. The findings show that daily migration of zooplankton in surface layer occurs in every observation period, average value of scattering volume in stratified depth of $0-25$ meter is $-84.19 \mathrm{~dB}$. For stratified depth of $25-50$ meter, scattering volume reaches $-81.81 \mathrm{~dB}$. At 00:00-03:00, zooplankton is concentrated densely at three water layers by SV value of 84.25, $-81.88,-83.9 \mathrm{~dB}$. Zooplankton aggregation is always almost at surface layer of 0-25 meter at every observation time. Allegedly, oceanographic factor with high concentration value of chlorophyll a are the reason. Concentration value of chlorophyll a in this depth may reach 2.1 $\mathrm{mg} / \mathrm{m}^{3}$. Calanoid contributes to value of scattering volume by regression formulation of $\mathrm{Y}=-8.93+0.01$ Calanoida -0.001 Cyclopoida .
\end{abstract}

Keywords: Daily migration, Acoustic, Zooplankton, Scattering volume 


\section{Introduction}

For some decades lately, some monitoring strategies and techniques have been undertaken to conduct study in the sea. The more information researchers may obtain, the better decision to determine seashore or coastal status as well as specific documents concerning water parameter (Conoghan and Guinard, 1998).

Zooplankton is drifting in or floating in animals living in ocean. Its ability to float is restricted, so it depends on where the current flows. Zooplankton does diurnal migration from the down layer up to surface layer. Knowledge on three-dimensional space planning to population and structural changes of zooplankton over time is a fundamental matter for the study on community dynamics of plankton (Chu et al., 1992). Tidal diurnal variation occurs in all water columns, but diurnal cycle of backscattering zooplankton only occurs above thermocline due to this migration of zooplankton.

Acoustic instrument is an effective instrument to detect and describe thin layer of zooplankton since zooplankton may be widely distributed. High-frequency acoustic has been utilized to find some methods in collecting data on distribution of zooplankton vertically or horizontally (Greene and Wiebe, 1998). Advantage of acoustic is data acquisition in high speed and real time without interfering organisms (Mac Lennan and Simmonds, 1992). Further, it is said that progression had been achieved during these decades, but it shall be emphasized that bioacoustical oceanography is recently discovered. However, acoustics field has the potential of solving a number of important problems on biological oceanography (Linstrom and Nowlin, 1989).

Position of Banda Sea is so strategic in determining process of oceanographic changes in Maluku water since Banda Sea is located in Maluku Islands. With the size of 500*1,000 km, this sea is far from Pacific Ocean and it is split up by hundreds of islands and Halmahera and Seram Sea. Depth of Banda Sea may reach 3,000 m where zooplankton living therein belongs to oceanic zooplankton. Diurnal migration of zooplankton in oceanic zone is different from semi-closed water, coastal area, or estuary. Banda Sea is oceanic zone having wide epipelagic zone where light intensity is quite exist, but it is poor in nutrient content. Nutrient concentration in the sea is very dynamic as affected by sea current and season. So does plankton abundance which changes depending on nutrient concentration (Nontjie, 2007).

As explained above, there had been executed a study on daily migration of zooplankton in Banda Sea. The study aims to analyze daily migration of zooplankton in Banda Sea and contribution of Calanoida to scattering volume which is greatly relating to oceanographic factor and food availability. Thus, it is expected that the study will contribute to marine world concerning to aggregation phenomenon of zooplankton in oceanic zone in Indonesia.

\section{Methodology}

The study is conducted in Banda Sea on November 21st-30th, 2013. The study applies exploratory description method by direct survey to the observed object, i.e. zooplankton in Banda Sea. 
Acoustic data sampling is conducted in every station, data recording is taken every one hour by drifting technique where Baruna Jaya VII vessel is utilized as floating platform. Acoustic data is collected by Simrad EK 500 at frequency of $38 \mathrm{kHz}$. Collected data, then is processed by software Echoview 4.8. Oceanographic data is processed by CTD Sea-Bird 911. Data sampling of zooplankton is taken in depth of 0,25 , and 75 meter by utilizing Roxete Sea Bird in the determined depth in every observation station. Zooplankton analysis utilizes standard system for zooplankton analysis. Acoustic data of zooplankton is collected for every observation station. Analysis is given by observing time of data sampling in every observation station.

Identification of zooplankton covers tabulation of taxa based on time and depth, identification of zooplankton species where the data is very useful for zooplankton verification concerning to oceanographic factor which form zooplankton aggregation.
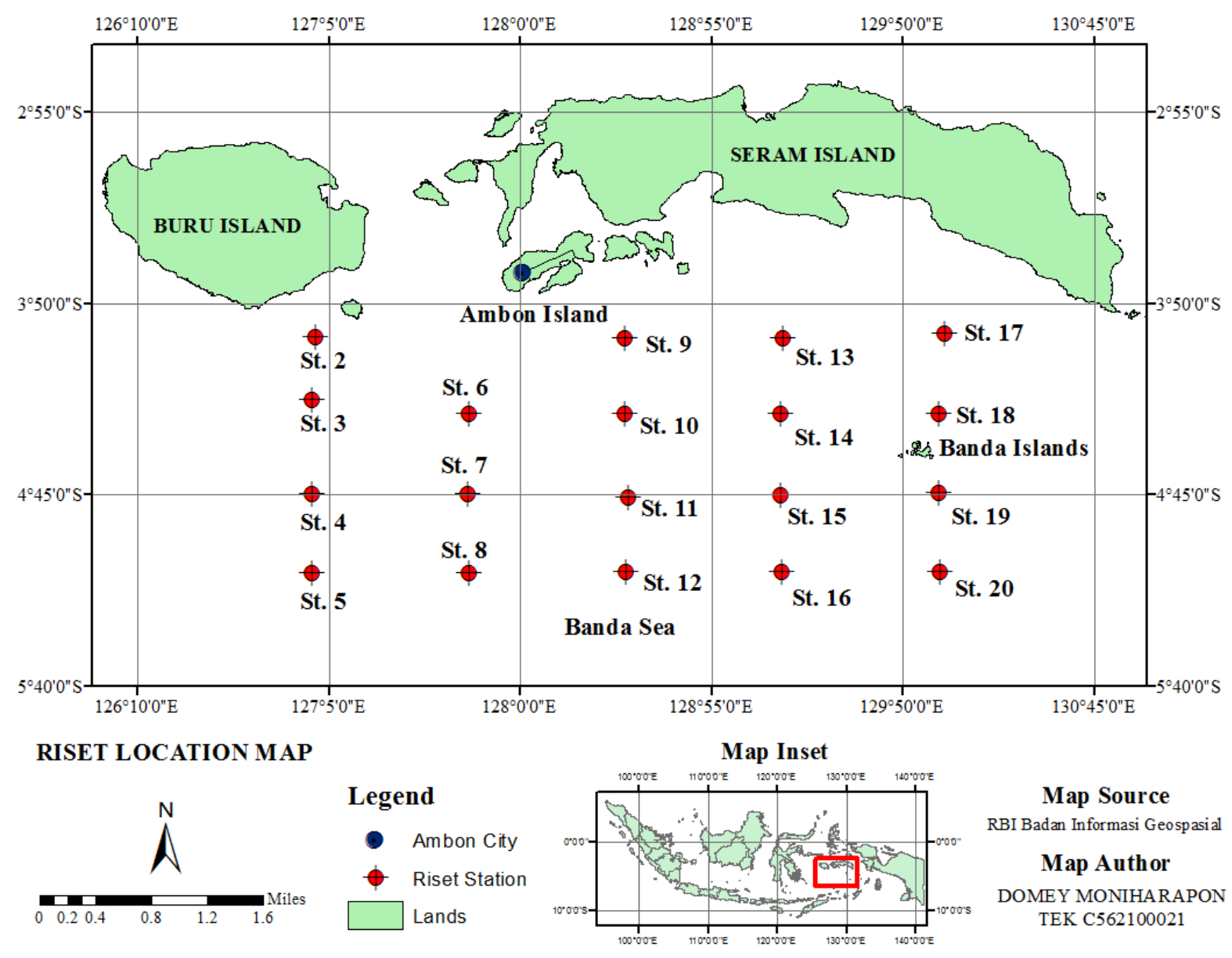

Figure 1. Research Site in Banda Sea

Backscattering volume is calculated in $\mathrm{dB}$, while SV depends on numeric abundance and species of the scatters in volume unit which responds in form of reverse echo. Resulting scattering volume is summation of every zooplankton organism as formulated below (Stanton et al., 1994): 


$$
\mathrm{SV}=\mathrm{N}_{\mathrm{a}} \sigma_{\mathrm{a}}+\mathrm{N}_{\mathrm{b}} \sigma_{\mathrm{b}}=\sum_{\mathrm{i}=1}^{m} \mathrm{~N}_{\mathrm{i}} \sigma_{\mathrm{i}} \quad(\mathrm{dB})
$$

Description:

$$
\begin{aligned}
\sigma_{a, b} & =\text { Back Scattering Strength }(\mathrm{dB}) \\
\mathrm{N}_{\mathrm{a}, \mathrm{b}} & =\text { Amount of species-based zooplankton }
\end{aligned}
$$

Sample of zooplankton is collected by utilizing Van Dorn water sampler, while species identification applies standard system for zooplankton identification. Abundance of zooplankton is calculated by applying the following formulation (Wickstead, 1965):

$$
\mathrm{D}=\mathrm{n} \times 1 / \mathrm{f} \times 1 / \mathrm{v} \quad\left(\mathrm{Ind} / \mathrm{m}^{3}\right)
$$

Description: $\mathrm{n}=$ Amount of individual zooplankton (tail)

$$
\begin{gathered}
\mathrm{f}=\text { Utilized fraction }(\mathrm{ml}) \\
\mathrm{v}=\text { Filtered water volume }(\mathrm{l})
\end{gathered}
$$

\section{Findings and Discussion}

\subsection{Daily Migration}

The study conducted in Banda Sea (Figure 1) makes special zooplankton aggregation based on time and depth.

Table 1. Value of time- and depth-based scattering volume

\begin{tabular}{rccc}
\hline Time & \multicolumn{2}{c}{ Scattering volum $(\mathrm{dB})$} & \\
\hline & $0-25$ & $25-50$ & $50-75$ \\
\hline $09: 00-12: 00$ & -84.76 & -82.17 & - \\
12:00-15:00 & -83.70 & - & - \\
15:00-18:00 & -84.81 & - & \\
18:00-21:00 & -83.24 & - & - \\
21:00-00:00 & -85.75 & - & -83.9 \\
$00: 00-03: 00$ & -84.25 & -81.88 & - \\
$03: 00-06: 00$ & -83.50 & - & - \\
$06: 00-09: 00$ & -83.94 & - & \\
\hline
\end{tabular}

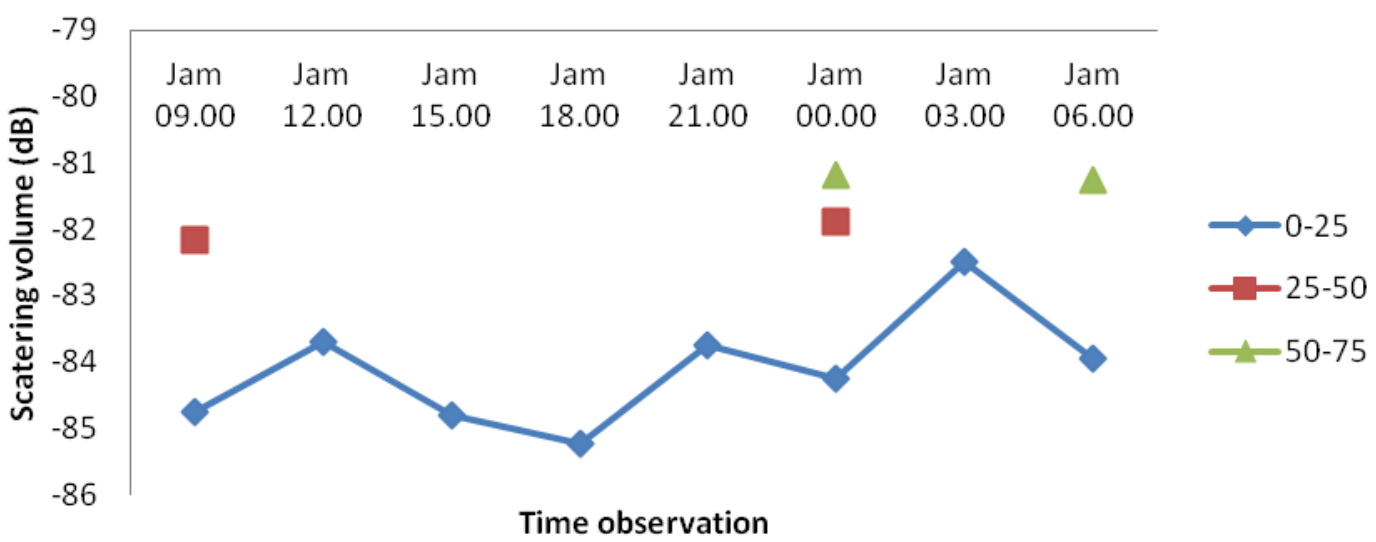

Figure 2. Value Plot of Time- and Depth-based Scattering Volume 


\section{Macrothink}

Table 1 and Figure 2 show zooplankton distribution existing in surface layer of 0-25 meter at every observation time. In depth of 25-50 meter, zooplankton only exists at 09:00 and 00:00. At 00:00, distribution of zooplankton exists in three zones, i.e. in depth of 0, 25, and 50 meter. Values of scattering volume are varied at every observation time and depth. In depth of 0-25 meter, maximum value of scattering volume is $-83.24 \mathrm{~dB}$, while the lowest volume is -85.75 $\mathrm{dB}$. Value of scattering volume is expression of numeric density of zooplankton. According to Stanton et al., (1994), value of 100 organisms is greater than 1 or 10 organisms. It indicates that more organisms means higher value of scattering volume. At 00:00, zooplankton crams those three depth layers by scattering volume of $-84.25,-81, .88$, and $-83.9 \mathrm{~dB}$ respectively. It indicates that at this time, zooplankton fills this depth layer. Sometimes, vertical migration of zooplankton may occur in three depth layers (Sutomo et al., 1994).

Nocturnal migration is migration undertaken by zooplankton from deeper layer to shallower layer at night (Hutchinson, 1967).According to Bayli (1986), this phenomenon is special migration exhibited by most of zooplankton species.

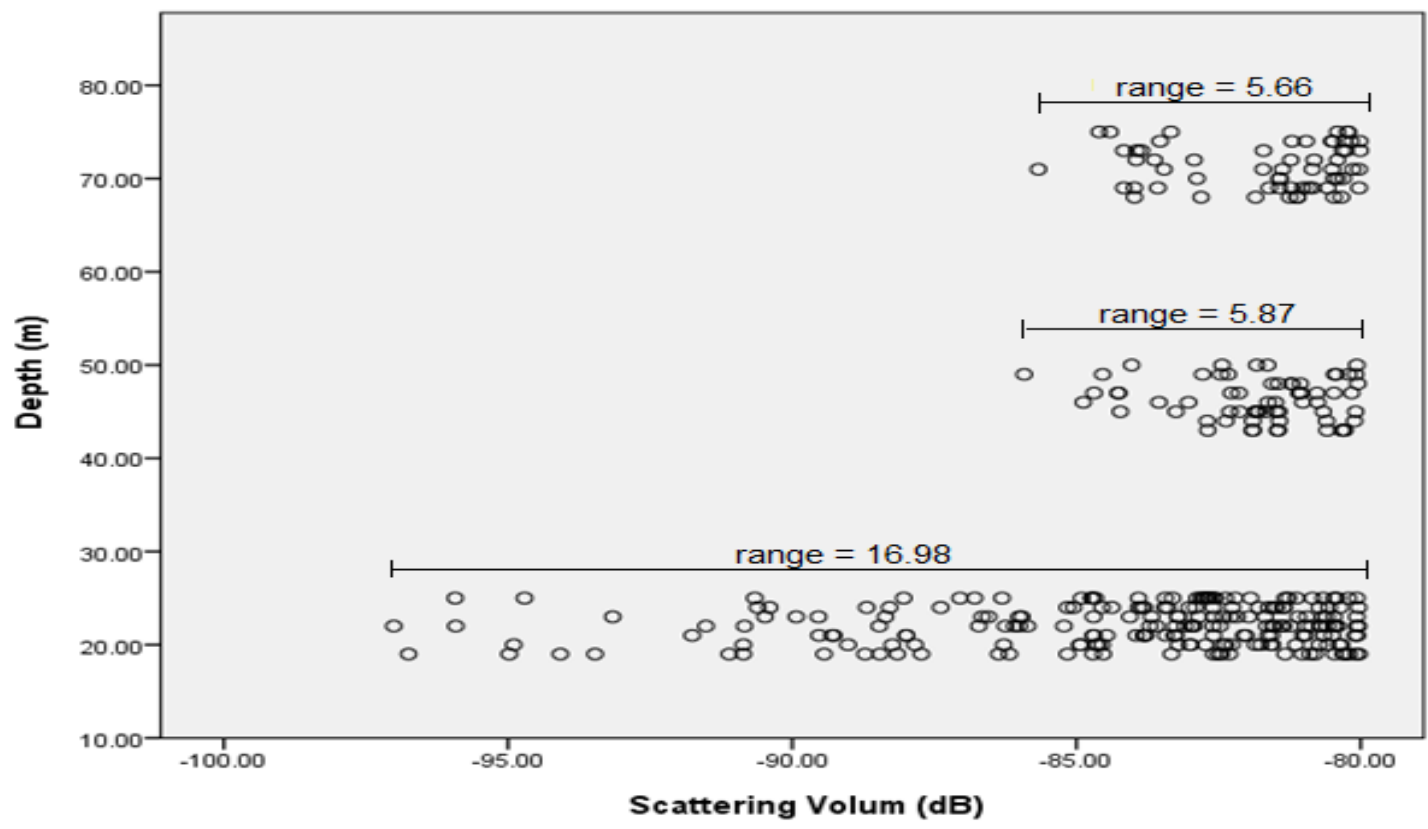

Figure 3. Distribution of Depth-based Zooplankton

Table 2. Descriptive statistics of zooplankton

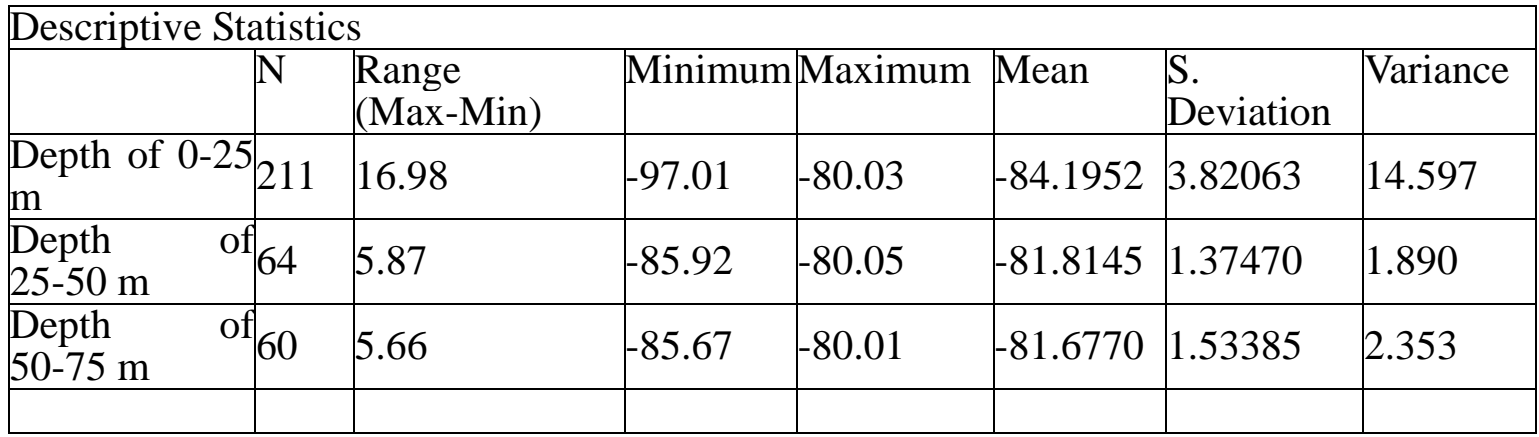


Zooplankton distributes dominantly to depth layer of 0-25 meter. In this stratified depth, there exists a very dense zooplankton where 211 groups lives herein by minimum value of scattering volume of $-97.01 \mathrm{~dB}$ and maximum value of $-84.19 \mathrm{~dB}$ and average value of -84.19 $\mathrm{dB}$. In this layer, zooplankton distributes and forms aggregation and reaches range of scattering volume of $16.98 \mathrm{~dB}$ and deviation standard of 3.86. It indicates that zooplankton forms various aggregations. There are 64 aggregations in depth of 25-50 meter where minimum value of scattering volume is $-85.92 \mathrm{~dB}$, maximum value is $-80.05 \mathrm{~dB}$, and deviation standard is 1.8. In depth of 50-75 meter, there exists 60 aggregations by minimum value of scattering volume is $-85.67 \mathrm{~dB}$, maximum value is -80.01 , and deviation standard is 1.5 (Figure 3). In general, at this depth, there exists slight diversity and enough dense aggregation.

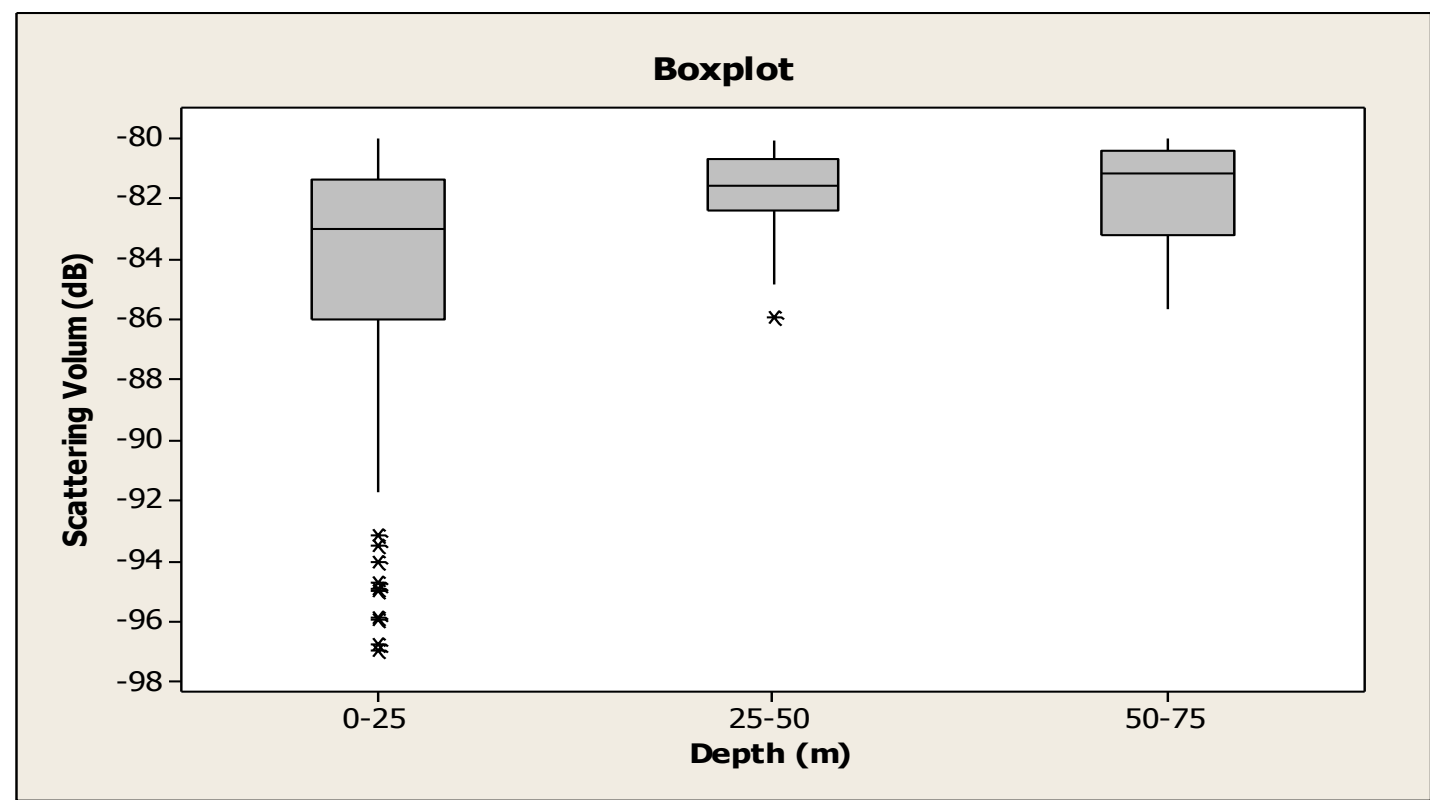

Figure 4. Value of Scattering Volume and Depth Boxplot

The highest aggregation variety exists in depth of 0-25, even an isolated aggregation. The longest range value of scattering volume exists in depth of 0-25 meter, while the shortest one is in depth of 25 to 50 meter. The lowest average value occurs in depth of 0-25 meter and the highest one is in depth of 50 to 75 meter (Figure 4). It indicates that zooplankton in depth of 0-25 distributes evenly in water column, while in depth of 50-75 meter, zooplankton does not distribute, but it forms dense aggregation. According to Dahuri and Rais (2013), open sea belongs to oceanic water having euphotic zone in the surface. This zone receives enough sunlight and gives high primary productivity; sometimes, it reaches 50 meter deep.

\subsection{Composition of Zooplankton}

Analysis result on biological composition of zooplankton is presented in Figure 5. It displays that family calanoida dominates composition of zooplankton, abundance of calanoida is 39,550 , cyclopida is $15,800 \mathrm{ind} / \mathrm{m}^{3}$,Herpactioda reaches $4,400 \mathrm{ind} / \mathrm{m}^{3}$, Ostracoda reaches $1,250 \mathrm{ind} / \mathrm{m}^{3}$, Sergestidae reaches $2,200 \mathrm{ind} / \mathrm{m}^{3}$,Urochorodatareaches $9650 \mathrm{ind} / \mathrm{m}^{3}$ and Meroplankton reaches $14,550 \mathrm{ind} / \mathrm{m}^{3}$. Ecologically, Nybakken (1992) asserts that one family 


\section{Macrothink}

plankton is dominated by class copepoda and phylum crustacean that dominate $50-80 \%$ of plankton in the ocean, class calanoida belongs to this group reaching abundance percentage of $45 \%$. It is detected that there are 7 families of zooplankton in this study, they are: Calanoida has abundance percentage of $45 \%, 18 \%$ for Cyclopoida, $17 \%$ for Meroplankton, $11 \%$ for Urochrodata, $5 \%$ for Harpactioda, 3\% for Sergestidae, and 1\% for Osracoda. (Figure 6)
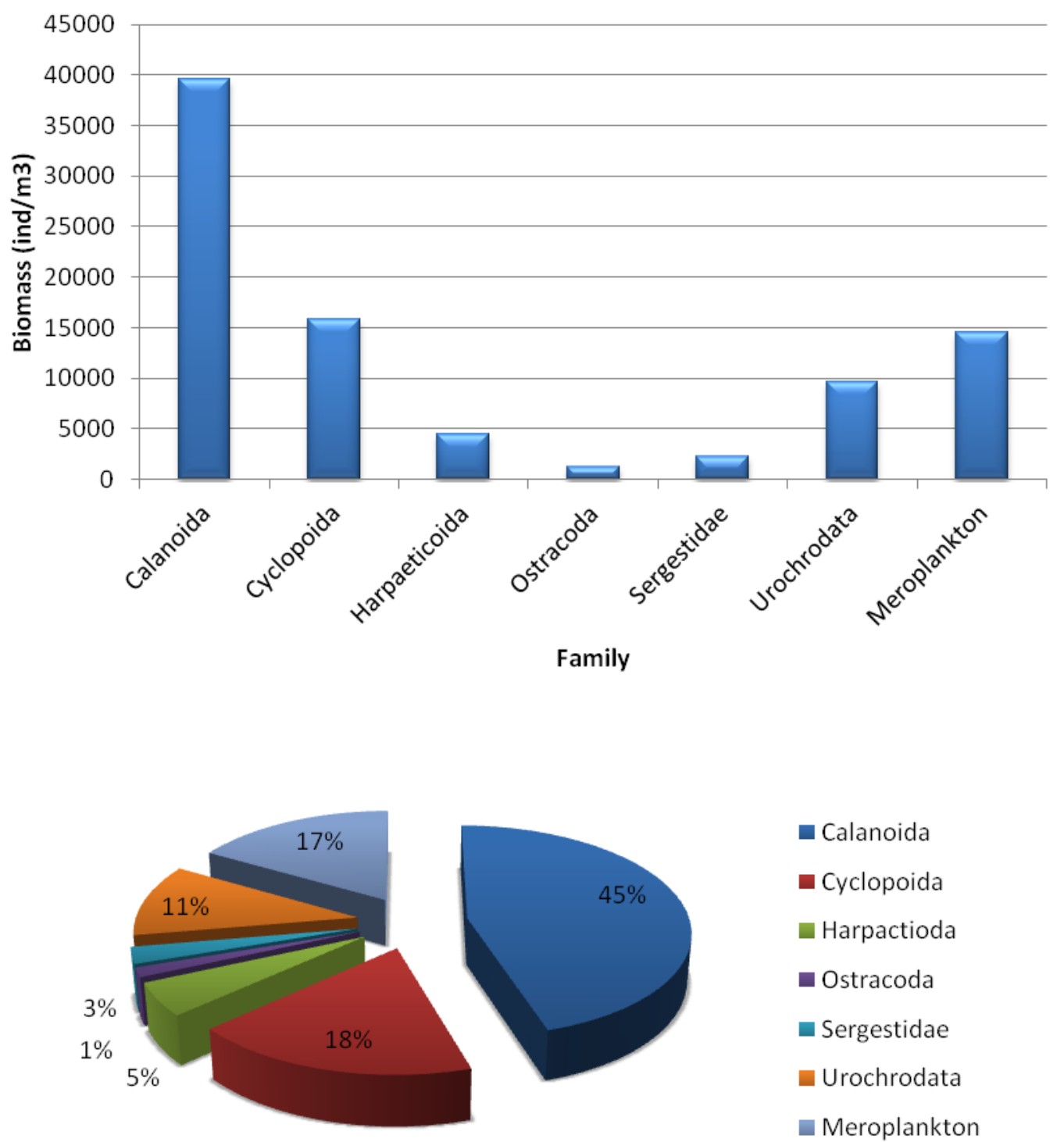

Figure 5. Amount of individual zooplankton based on family

Noguira and Panarelli (1997), conduct vertical migration research on cladecerans and they found that phenomenon of nocturnal migration is also performed by this species. Movement pattern of this family gets close to water column at afternoon until midnight. According to Hutkinson (1967), species performing this movement is copepod which systematically performs nocturnal movement, calanoida and cyclopoida are family belonging to class 
copepod. Adaptive value of behavior and oceanographic factor and also food-foraging movement are the other factors in nocturnal migration (Ohman, 1990; Ruttner, 1975). Body composition of copepod consists of obvious segments and it is divided into two major segments, i.e. metasome andurosome, it has calcareous and hard skin which this composition, presumably, will affect greatly value of scattering volume.

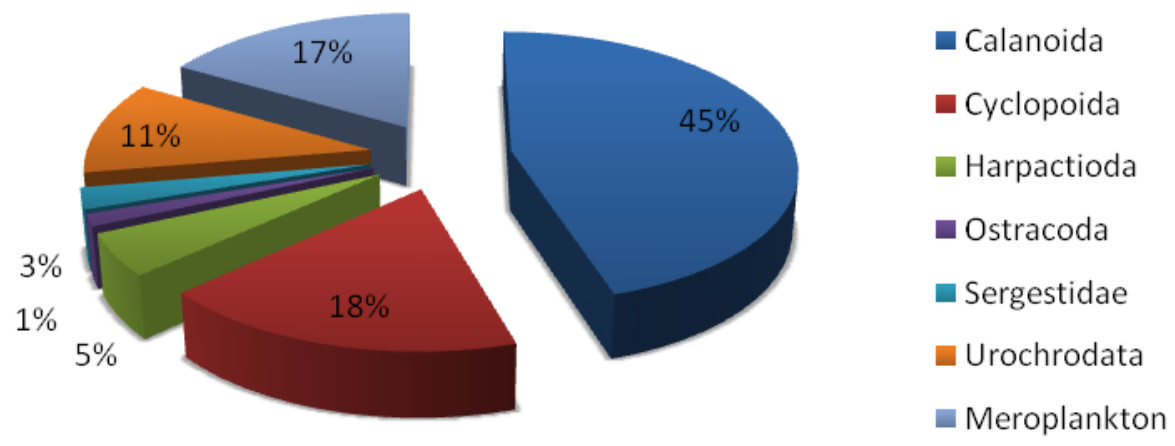

Figure 6. Abundance Percentage Based on Zooplankton Group in Banda Sea

\subsection{Oceanography of Zooplankton}

Temperature in Banda Sea is $22.19^{\circ} \mathrm{C}$ at minimum degree and $29.13^{\circ} \mathrm{C}$ at maximum degree. Temperature range for marine organism is $20-30^{\circ} \mathrm{C}$. Salinity has an important role in organism life like distribution of aquatic biota which relates closely to salinity (Nybaken, 1982).

Salinity value in Banda Sea in this study is 33.83 PSU in surface layer, and 34.32 PSU in depth of 100 meter. Salinity is so important to study distribution of organism and water mass movement. Horizontal distribution of salinity depends on latitude width which relates closely to evaporation and precipitation. At the same time, vertical distribution relates to difference of sun radiation received by surface layer. Banda Sea is oceanic water where salinity does not depend on surface runoff or rivers, but salinity change is almost triggered by evaporation and precipitation. Concerning to food chain, it is proved that zooplankton is food source for all pelagic fishes. Therefore, abundance of zooplankton is often connected to water fertility (Arinardi, et al., 1997).

Figure 7 points out distribution of chlorophyll-a concentration is in surface zone, i.e. around 10-80 meter. This concentration greatly affects the existence of zooplankton. Water possessing high rate of chlorophyll-a concentration indicates that the water is fertile. When survey is taken, chlorophyll concentration reaches $2.1 \mathrm{mg} / \mathrm{m}^{3}$. Zone having high chlorophyll-a concentration possesses great number of phytoplankton. Presumably, chlorophyll-a concentration highly affects daily migration of zooplankton. Linear regression 


\section{Macrothink}

Journal of Environment and Ecology

ISSN 2157-6092

2014, Vol. 5, No. 1

proves that relationship between abundance and chlorophyll-a is so strong amount to $\mathrm{r}=0.934$.
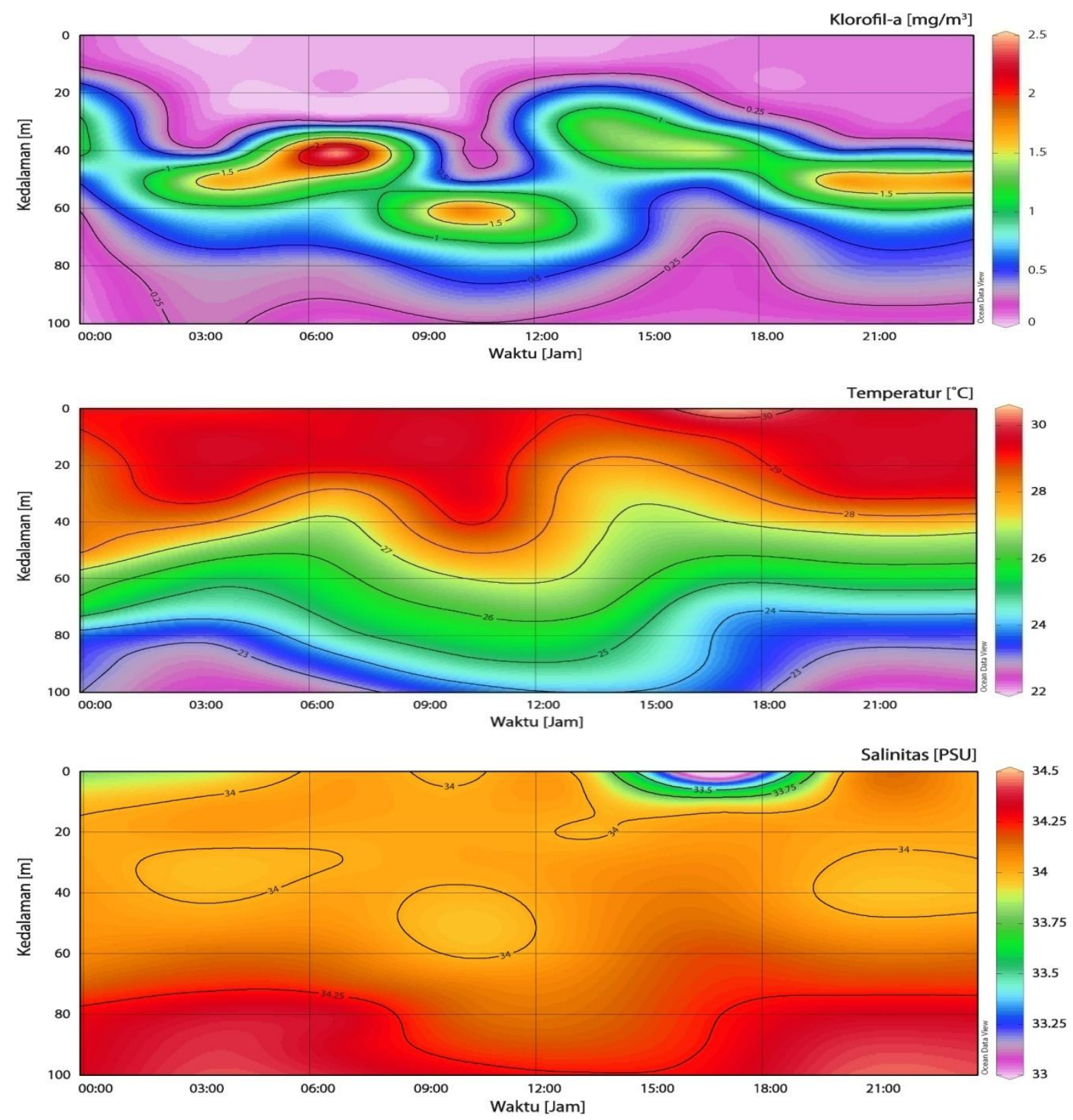

Figure 7. Oceanographic Transverse Distribution in Banda Sea

Naturally, zooplankton will consume phytoplankton as in oceanic food chain. According to Davis (1995), abundance of zooplankton is highly affected by the presence of phytoplankton since the latter is food of zooplankton. It is supported by Arinardi (1977) asserting that abundance of zooplankton is just determined by density of phytoplankton. It occurs since phytoplankton is food of zooplankton.

Temperature in Banda Sea is $22.19^{\circ} \mathrm{C}$ at minimum degree and $29.13^{\circ} \mathrm{C}$ at maximum degree. Temperature range for marine organism is $20-30^{\circ} \mathrm{C}$. Salinity has an important role in the organism life, such as distribution of aquatic biota which relates closely to salinity (Nybaken, 1982). 


\section{Macrothink}

Vertical migration of zooplankton really depends on response and adaptation of this organism toward variation of environmental changes like sunshine, temperature, salinity, oxygen, food, and predator (Steinberg et al., 2002). Further, according to Cisewski et al. (2010), in general, it is acceptable that daily cycle of sunshine has an important role in daily migration behavior of zooplankton since the sunlight is the major energy source in controlling water ecosystem.

\subsection{Contribution of Calanoida to Scattering Volume}

The study points out that family calanoida along with its efficiency in performing migration, calanoida belongs to dominant family based on biological sample taken from the whole water columns. Further analysis to understand contribution of family zooplankton affecting value of scattering volume is undertaken according to biological character and numerical density.

Biological analysis result as in Figure 6 figures calanoida and cyclopoida belongs to dominant family that contributes to value of scattering volume of zooplankton in waters. Therefore, density values of both families are made as predictors in multiple linear regression analysis. Independent variable for regression analysis is value of scattering volume, while dependent variables are Calanoida and Cyclopoida. Correlation value of scattering volume and abundance indicates strong relationship of $\mathrm{R}=0.432$ and $\mathrm{R}^{2}=0.186$.

\begin{tabular}{|l|l|l|l|l|}
\hline \multicolumn{5}{|l|}{ Summary Model } \\
\hline Model & $\mathrm{R}$ & R Square & $\begin{array}{l}\text { Adjusted } \\
\text { Square }\end{array}$ & $\begin{array}{l}\text { RStd. Error of } \\
\text { the Estimate }\end{array}$ \\
\hline 1 & $.432^{\mathrm{a}}$ & .186 & .005 & 1.42427 \\
\hline
\end{tabular}

a. Predictors: (Constant), Cyclopoida, Calanoida

\begin{tabular}{|c|c|c|c|c|c|c|}
\hline \multicolumn{7}{|c|}{ ANOVA $^{a}$} \\
\hline Model & & Sum & of df & Mean Square & $\mathrm{F}$ & Sig. \\
\hline \multirow{3}{*}{1} & Regression & 4,179 & 2 & 2,089 & 1,030 & $396^{\mathrm{b}}$ \\
\hline & Residual & 18,257 & 9 & 2,029 & & \\
\hline & Total & 22,436 & 11 & & & \\
\hline
\end{tabular}

a. Dependent Variable: Scattering_Value

b. Predictors: (Constant), Cyclopoida, Calanoida 


\begin{tabular}{|c|c|c|c|c|c|c|}
\hline \multicolumn{7}{|c|}{ Coefficients $^{\mathrm{a}}$} \\
\hline \multirow[t]{3}{*}{ Model } & & \multirow{2}{*}{\multicolumn{2}{|c|}{$\begin{array}{l}\text { Unstandardized } \\
\text { Coefficients }\end{array}$}} & Standardized & \multirow[t]{3}{*}{ t } & \multirow[t]{3}{*}{ Sig. } \\
\hline & & & & Coefficients & & \\
\hline & & B & Std. Error & Beta & & \\
\hline \multirow{3}{*}{ 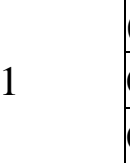 } & (Constant) & -83.930 & .644 & & -130.279 & .000 \\
\hline & Calanoida & .001 & .000 & .752 & 1.334 & 215 \\
\hline & Cyclopoida & -.001 & .001 & -.476 & -.845 & .420 \\
\hline
\end{tabular}

a. Dependent Variable: Scattering_Value

Analysis on multiple linear regression delivers estimate value as follows:

Model

Scattering Value $=-83,93+0,001$ Calanioda $-0,001$ Cylopoida

It means that, presumably, value of scattering volume may be found out by calculating abundance value of Calanoida and Cyclopoida through the multiple regression formula.

\section{Conclusion}

Average scattering value in stratified depth of 0-25 meter is $-84.19 \mathrm{~dB}$.For stratified depth 25-50 meter, scattering volume reach -81.81 dB. At 00:00-03:00, zooplankton is concentrated densely at three water layers by SV value of $-84.25,-81.88,-83.9 \mathrm{~dB}$.

Zooplankton aggregation is always almost at surface layer of 0-25 meter at every observation time. Allegedly, oceanographic factor with high concentration value of chlorophyll a are the reason. Concentration value of chlorophyll a in this depth may reach $2.1 \mathrm{mg} / \mathrm{m}^{3}$.

Calanoida and Cyclopoida contribute to scattering volume by regression formulation of $\mathrm{Y}=-83.93+0.001$ Calanoida-0.001 Cyclopoida . It indicates that by finding out zooplankton abundance, there will be found the scattering volume.

\section{Credits}

My best gratitude to Head of Ocean Acoustics Laboratory, Bogor Institute of Agriculture for the data processing facilities, Head of Ocean Conservation Research Station, The Indonesian Institute of Sciences (LembagaIlmuPengetahuan Indonesia or LIPI), Ambon for providing us equipments and facility of Baruna Java VII vessel for this study. Colleagues in the field: AsepMa'mun, S.Pi, Pa Bob Latumeten, Ir J Lekalette, Aunt Omi, FerdyHukom, Mrs. James, Mrs. Angky, Mrs. JemiTatipata, crews of Baruna Jaya VII vessel. for all of their helps and jokes during the research.

\section{References}

Arinardi, O. H. (1997). Status pengetahuan Plankton di Indonesia. Oseanologi dan Limnologi di Indonesia. Puslitbang - LIPI. Jakarta.

Bayli, I. A. H. (1986). Aspects of diel vertical migration in zooplankton and its enigma variations. Limnologi in Australia.CSIRO Aust, Melbourne, Australia, 349- 368. 


\section{Macrothink}

Journal of Environment and Ecology ISSN 2157-6092 2014, Vol. 5, No. 1

Chu, D., Wiebe P., \& Copley, N. (1992). Interference of material properties of zooplankton FromAcoustic and resistivity measurement. ICES Journal of marine science, 57, 1128-1142. http://dx.doi.org/10.1006/jmsc.2000.0800

Cisewski, B., Strass, V. H., \& Rhein, M. (2010). Seasonal variation of diel vertical migration of Zooplankton from ADCP backscatter time series data in tehe Lazarev sea.Antartica. Deep sea Research I, 57, 78-94. http://dx.doi.org/10.1016/j.dsr.2009.10.005

Conogan, R., \& Guinard, J. P. (1998). Observing operationally in situ ocean parameters. The EMMA System. IEEE ocean' 98. Nice.

Dahuri, R., \& Rais, J. (2013). Pengelolaan sumber daya pesisir da lautan secara terpadu.B.P Jembatan.Jakarta, p328.

Greene, C. H., \& Wiebe, P. H. (1998). New devolepments in bioacoustical oceanography. Sea Technol. 229, 27-29.

Hutabarat, S., \& Evans, S. M. (1985). Pengantar Oseanografi. Universitas Indonesia Press. Jakarta. $159 \mathrm{p}$

Hutckinson, G. E. (1967). A treatise on Limnology II. Introduction to Lake Biology and the Limnoplankton. John Wiley \& sons. New York. USA. 570p.

Lindstrom, E. J., \& Nowlin, W. D. (1989). Impetus for new instrument development. Sea Technol, 30, 31-37

Mac Lennan, D. N., \& Simmonds, E. J. (1992). Fisheries Acoustic. Chapman and Hall. p325.

Nogueira, M. G., \& Panarelli, E. (1997). Estudo da miracho vertical das populaces zooplanktonicas na represa de jurumirim (RioParapanema. Sao Paulo.Brasil). Acta Limnologica Brasiliensia, 9, 55-81.

Nontjie, A. (1987). Laut Nusantara.Penerbit Djambatan . Jakarta.

Nybakken, J. W. (1992). Biologi laut ; Suatu Pendekatan Ekologis. Alih bahasa Eidman dkk. P.T Gramedia Pustaka Utama. Jakarta.

Ohman, M. D. (1990). The demographic benefis of diel vertical migration by zooplankton Ekological Monograph, 60, 257-281.

Ruttner, F. (1975). Fundamental of Limnology. University of Toronto Press. Toronto.

Stanton, T. K.,Wiebe, P. H., Chu, D., Benfield, M. C., Scanlon, L., \& Martin, L. (1994). On acoustic Estimation of zooplankton biomass. ICES. J. Mar. Sci, 51, 502-512. http://dx.doi.org/10.1006/jmsc.1994.1051

Steinberg, D. K., Goldthwait, S. A., \& Hansel, D. A. (2002). Zooplanon vertical migration and TheActive transport of dissolved organic and inorganic nitrogen in the Sargasso sea. Deep Sea Research I 49, 1445-1461. http://dx.doi.org/10.1016/S0967-0637(02)00037-7

Sutomo, A. B., \& dan Nugroho, D. (1994). Penggunaan Fish finder dan jaring Nansen untuk 
studi migrasi vertikal zooplankton.Makalah dibacakan pada symposium perikanan Indonesia. Jakarta 25-27 Agustus 1993.

Wickstead, J. H. (1965). An introduction to the study of tropical plankton, 1, 1-60. London. Hutchinson Tropical Monograph. 